Open Access

\title{
A structural equation modeling analysis of relationships among university students' readiness for e-learning, self-regulation skills, satisfaction, and academic achievement
}

\author{
Nuh Yavuzalp ${ }^{1^{*}}$ (i) and Eralp Bahcivan ${ }^{2}$ (i)
}

\footnotetext{
*Correspondence: nuhyavuzalp@ gmail.com

${ }^{1}$ Faculty of Education, Department of Computer Education \& Instructional Technologies, Bolu Abant Izzet Baysal University, Bolu, Turkey

Full list of author information is available at the end of the article
}

\begin{abstract}
The aim of this study is to examine the relationships of readiness for e-learning with self-regulation skills, satisfaction, and academic achievement in university students taking campus-based courses via distance learning. In this context, a structural equation model is proposed by taking studies in the literature into consideration. The proposed model is analyzed and discussed in the light of the literature. A total of 749 university students from a state university in Turkey participated voluntarily in the study. A scale of readiness for e-learning, a self-regulated online learning scale, and a satisfaction survey were used as data collection tools in the study. The fit index values obtained from the analysis were observed to be $x^{2} / d f=4.11, C F I=.90$, and RMSEA $=.06$, which were at an acceptable level. The research results reveal that the university students' readiness for e-learning was effective on their self-regulation skills, satisfaction, and academic achievement. Implementation suggestions are made in line with the research findings and conclusions.
\end{abstract}

Keywords: E-learning, Readiness for e-learning, Self-regulated learning, Satisfaction, Achievement

\section{Introduction}

The number of educational institutions providing education via distance learning has been increasing recently, especially due to the Covid-2019 pandemic. Advantages of elearning mediums in terms of time and space provided it to come into the forefront (Nwagwu, 2020). During this session, university students could not participate the lessons physically; instead, they took courses via distance education system in many countries. However, sufficient importance is not given to the individual and technical prerequisites necessary for enabling success and satisfaction in these educational institutions (Pillay, Irving, \& Tones, 2007). For university students to be able to benefit from the advantages of online courses that they take via distance learning, they need to

(c) The Author(s). 2021 Open Access This article is licensed under a Creative Commons Attribution 4.0 International License, which permits use, sharing, adaptation, distribution and reproduction in any medium or format, as long as you give appropriate credit to the original author(s) and the source, provide a link to the Creative Commons licence, and indicate if changes were made. The images or other third party material in this article are included in the article's Creative Commons licence, unless indicated otherwise in a credit line to the material. If material is not included in the article's Creative Commons licence and your intended use is not permitted by statutory regulation or exceeds the permitted use, you will need to obtain permission directly from the copyright holder. To view a copy of this licence, visit http://creativecommons.org/licenses/by/4.0/. 
possess certain technical and educational skills. In this context, a number of studies have been conducted that investigate the success of and student satisfaction with online courses taken via distance learning (Dikbas Torun, 2020; K.M. Lin, 2011; Ozturk, Ozturk, \& Ozen, 2018; Paechter, Maier, \& Macher, 2010; Wu, Tennyson, \& Hsia, 2010; $\mathrm{Zhu}, 2012)$. In its simplest terms, e-learning expresses access, from the desired location and at the desired time, to the material and components required for learning in an online environment (Holmes \& Gardner, 2006). As online or internet-based distance learning has become more widespread recently, many expert educators have begun to inquire about the extent to which distance learning students are prepared in order to be successful in this environment (Watkins \& Corry, 2005).

In this context, it is important to determine the previous learning experiences of students who have certain expectations from e-learning environments and the degree to which they are prepared for e-learning, so that these environments can be correctly and effectively designed and utilized (Hukle, 2009). For a higher education institution, readiness for new technologies is essential for the desired effects to be observed in areas like productivity and expected benefit (Machado, 2007). When the related literature is examined, there are certain studies investigating students' readiness for using technologysupported products and the effects of this variable on their behaviors (J.S.C. Lin \& Hsieh, 2007). In this study, readiness for e-learning concept was used to refer e-readiness. While organizing learning activities in e-learning processes, in terms of enabling greater flexibility, students should be able to have control over their own learning activities and make their own decisions regarding the scope and depth of content, the type of media accessed, and the time spent on study. In this respect, the student control dimension, and at the same time, student readiness is regarded as an important part of e-learning (Stansfield, McLellan, \& Connolly, 2004). Also, examining students' readiness and awareness regarding e-learning mediums contribute positively to the developmental studies in this area (Dikbas Torun, 2020). Sufficient evidence can be found in the literature stating that the variables mentioned here have an effect on a number of characteristics, principally on achievement (A.R. Artino, 2010; Keramati, Afshari-Mofrad, \& Kamrani, 2011; Klein, Noe, \& Wang, 2006; Muilenburg \& Berge, 2005). However, no academic study can be found which deals with all these variables together.

At University, where this study was carried out, approximately 9000 students register every academic year for campus-based courses conducted via distance learning. Examination of the variables considered to be effective for these students' satisfaction and academic achievement is an important research subject. Therefore, investigation of the psychological and sociological variables that may affect university students' success in e-learning environments is important in scientific terms. Pandemic session has already shown the added-value of e-learning systems. In this context, determining the effects of undergraduate and postgraduate students' readiness for e-learning and self-regulation skills for online environments on their satisfaction and academic achievement has an effective value in terms of offering students a better distance learning environment and supporting student success. Most probably, results of such research studies will be important not only during pandemic session but also after the session. 


\section{Theoretical framework}

\section{Readiness for e-learning}

Readiness for e-learning is defined by Lopes (2007) as the ability of any organization or individual to benefit from the advantages offered by e-learning. Kaur and Abas (2004) define readiness for e-learning as individuals' ability to utilize e-learning resources and multimedia technologies with the aim of increasing the quality of learning. Readiness for e-learning expresses the student's possession of the prerequisite knowledge, skills, and beliefs required for learning in such an environment (Warner, Christie, \& Choy, 1998). Similarly, Alem, Plaisent, Zuccaro, and Bernard (2016) stated that e-learners require certain skills and orientations to overcome issues related to e-learning mediums. In other words, readiness for e-learning is, in short, the degree to which an individual or organization possesses the prior knowledge/skills and effective characteristics (attitude, motivation, etc.) required for experiencing e-learning in the most effective way (Yurdugül \& Demir, 2017).

Possession of readiness by students supports the advancement of e-learning and increases the quality of interaction in e-learning environments (Hukle, 2009). Therefore, for e-learning applications to be successful, students' readiness must be assessed prior to the process (So \& Swatman, 2006). Carrying out this assessment will make it possible for the aims of designing suitable e-learning strategies and of developing information and communication technology skills to be implemented effectively (Kaur \& Abas, 2004). In Valtonen, Kukkonen, Dillon, and Väisänen's (2009) study, it is emphasized that readiness for elearning among students without e-learning experience ranged between high, medium, and low levels. From this aspect, it is seen that even if they have no e-learning experience, students' levels of readiness may vary.

Readiness for e-learning consists of 6 dimensions, namely computer self-efficacy, internet self-efficacy, online communication self-efficacy, self-directed learning, learner control, and motivation toward e-learning (Hung et al., 2010). Among them, computer selfefficacy refers to abilities related to utilizing computers efficiently whereas internet selfefficacy focuses on internet-related tasks (Eastin \& LaRose, 2000). Moreover, online communication self-efficacy corresponds to learners' insistence to continue communicating and sharing knowledge with others through computer-assisted mediums. Next, selfdirected learning covers learners' evaluations about learning requirements. Then, learner control refers to beneficiaries' management of learning processes as well as controlling their individualized learning needs. Finally, motivation toward e-learning covers learners' intrinsic and/or extrinsic orientation related to comprehension (Hung et al., 2010).

It is stated in the literature that together with readiness for e-learning, there are relationships among a number of variables such as self-regulation skills for online environments, satisfaction, and academic achievement (A.R. Artino, 2009; M.H. Cho \& Kim, 2013; M.H. Cho \& Shen, 2013; Dikbas Torun, 2020; Ilgaz \& Gülbahar, 2015; Kruger-Ross \& Waters, 2013; Kuo, Walker, Schroder, \& Belland, 2014; S.S. Liaw \& Huang, 2013; Zhu, 2012). For example, C.K. Lim (2001) determined that computer self-efficacy, which is one of the sub-factors of readiness for e-learning, was a predictor of satisfaction in web-based distance learning classes. Similarly, Eastin and LaRose (2000) stressed that computer and internet self-efficacy resulted in both improved performance in technical subjects like downloading documents or online system management, and better performance in solving problems in online learning. Therefore, an 
increase in computer and internet self-efficacy can be considered to increase students' satisfaction and achievement. For example, Tsai and Tsai (2003) stated that students with higher levels of internet self-efficacy learned better in a web-based learning task than students with lower levels of internet self-efficacy.

Yakin and Tinmaz (2013) state that readiness for e-learning has a significant effect on users' adoption of technological innovations. In this regard, students' possession of adequate readiness is important for design and implementation of e-learning (Hukle, 2009; Ilgaz \& Gülbahar, 2015). For this reason, evaluation of students' readiness as well as their satisfaction with online courses is a necessary process in terms of the success of online learning applications (Gülbahar, 2012; Kaur \& Abas, 2004; Ozturk et al., 2018; So \& Swatman, 2006). To sum up, the literature clearly states that readiness for elearning is related to learners' self-regulation skills, satisfaction, and academic achievement (A.R. Artino, 2009; M.H. Cho \& Kim, 2013; M.H. Cho \& Shen, 2013; Dikbas Torun, 2020; Ilgaz \& Gülbahar, 2015; Kruger-Ross \& Waters, 2013; Kuo et al., 2014; S.S. Liaw \& Huang, 2013; Zhu, 2012). However, the relationships between these variables are not examined in a comprehensive model in the way that they are in the present study.

\section{Self-regulation}

Self-regulation focuses on individuals' responsibility for their own learning, control of their own learning processes, ability to adjust their learning process when necessary, and ability to motivate themselves throughout their learning lives (B.J. Zimmerman, 2011). Students who can self-regulate can take control of their learning processes by developing metacognitive strategies such as planning, being organized and being motivated (E. Yukselturk \& Bulut, 2007).

Studies show that self-regulation is critical for determining students' successful learning experiences in online learning environments (M.H. Cho \& Kim, 2013). It is known that students who can self-regulate are successful in setting goals, planning, and monitoring their learning processes and in evaluating these processes. It is expected that these students, who can manage their time and learning resources effectively (Pintrich, 2004; B.J. Zimmerman, 2011), will have successful learning experiences in online lessons by using their self-regulation skills for distance learning.

At the same time, self-regulated learning expresses students' systematic efforts toward managing their learning processes in order to achieve their goals (Pintrich, 2004; B.J. Zimmerman \& Schunk, 2011). Self-regulated learning is generally explained in the context of integration of motivation, emotion, and learning strategies (Abar \& Loken, 2010). Regarding motivation, students who possess self-regulation skills are disposed to gain competence by mastering the work that they do (Pintrich, 2004; B.J. Zimmerman, 2011). The conducted studies show that motivation, which is one of the components of selfregulation, and emotion have a significant effect on students' learning experiences such as achievement, satisfaction, and passing or failing the course (M.H. Cho \& Heron, 2015).

In some studies, an attempt has been made to explain the role of motivation in selfregulated learning. Among these, M.H. Cho and Kim (2013) revealed that students' mastery goal orientations and their interaction in online learning environments were positively correlated with their self-regulation. Moreover, M.H. Cho and Shen (2013) 
also revealed that in nonsynchronous online learning environments, metacognitive selfregulation was not only correlated with their learning and academic performance but was also positively related to their self-efficacy.

\section{Satisfaction}

Student satisfaction reflects the way students regard their learning experiences. In his evaluation of online learning quality determined by an online learning consortium, Moore (2005) states that together with learning effectiveness, faculty satisfaction, scalability, and access, student satisfaction is one of the five basic components. Satisfaction is a critical variable that affects a student's decision to take another online course (Kuo et al., 2014).

While student-student interaction plays an important role in student satisfaction, the quality and currency of student-teacher communication is also asserted to be an important determinant of student satisfaction, as supported by various experimental studies (Croxton, 2014). Among these examples, it is stated that up-to-dateness of instructor feedback affects the general course satisfaction of online undergraduate and graduate students (Walker \& Kelly, 2007). S.K. Parahoo, Santally, Rajabalee, and Harvey (2016) revealed that student-student interaction has an important effect on satisfaction. Similar findings have also been revealed by other researchers (Einarson \& Matier, 2005; Hollenbeck, Mason, \& Song, 2011; Ivankova \& Stick, 2007). Finally, certain researchers (e.g., A.R. Artino, 2009) mentioned that learners' self-regulation skills positively affected their satisfaction with e-learning.

The conducted studies state that levels of readiness for the internet and technology are among the most important factors expressing e-learners' satisfaction with learning management systems (LMS) (Parnell \& Carraher, 2003; R. Watkins, Leigh, \& Triner, 2004). Furthermore, learners' levels of online readiness are a directly effective structure for their success (A.R. Artino, 2009; Dikbas Torun, 2020; Galy, Downey, \& Johnson, 2011; Kruger-Ross \& Waters, 2013). On the other hand, with a different view, there are also studies stating that internet self-efficacy, which is one of the subdimensions of readiness for e-learning, is not related to or is not a predictor of student satisfaction (Kuo et al., 2014).

Students who have task value and a high level of self-efficacy for learning are likely to be satisfied with online courses. A.R. Artino (2009) revealed that motivation variables such as self-efficacy and task value were positive predictors of course satisfaction but that negative emotional variables like boringness and failure to meet expectations had a negative effect on course satisfaction. In another of his studies, A.R. Artino (2009) stated that motivation variables including self-efficacy and task value explained $43.4 \%$ of the variance in course satisfaction in an online learning environment.

In their online learning study, Kuo et al. (2014) found that students' internet selfefficacy, self-regulated learning, student-student interaction, student-teacher interaction, and student-content interaction were correlated with their satisfaction. S.S. Liaw and Huang (2013) found that satisfaction was related to self-efficacy, anxiety, and interactive learning environments. Consequently, it can be said that these variables are related to readiness for e-learning. 


\section{Academic achievement}

Student achievement emerges in the knowledge, skills, and behaviors acquired by any students in education environments, and this is also realized in their learning outcomes (Demirtas, 2010). On the other hand, it can be considered that in online learning environments developed with technological support, there are a number of factors that will affect student achievement. For example, M.H. Cho and Shen (2013) stated that students' self-regulation skills affected their academic achievement in online learning environments.

Furthermore, studies show that well-designed e-learning environments have a positive effect on student performance (K.S. Hong, 2002; K.S. Hong, Lai, \& Holton, 2003; Johnson, Hornik, \& Salas, 2008; S.S. Liaw, Huang, \& Chen, 2007. Moreover, Song, Singleton, Hill, and Koh (2004) state that for online learners, course design and time management are important components of successful online learning, while lack of communication and technical problems are complicating factors for students.

\section{The proposed model and hypotheses}

To examine the research problem, the relational model in Fig. 1 is suggested. The university students' readiness for e-learning, online self-regulation skills, satisfaction, and academic achievement expressed in the proposed model are based on studies in the literature.

To examine the research problem, by taking the above theoretical framework and empirical studies into consideration, the proposed research model presented in Fig. 1 includes five (5) hypotheses:

- H1: University students' readiness for e-learning (so their computer self-efficacy, internet self-efficacy, online communication self-efficacy, self-directed learning, learner control, and motivation toward e-learning) positively predicts their selfregulation skills for online environments.

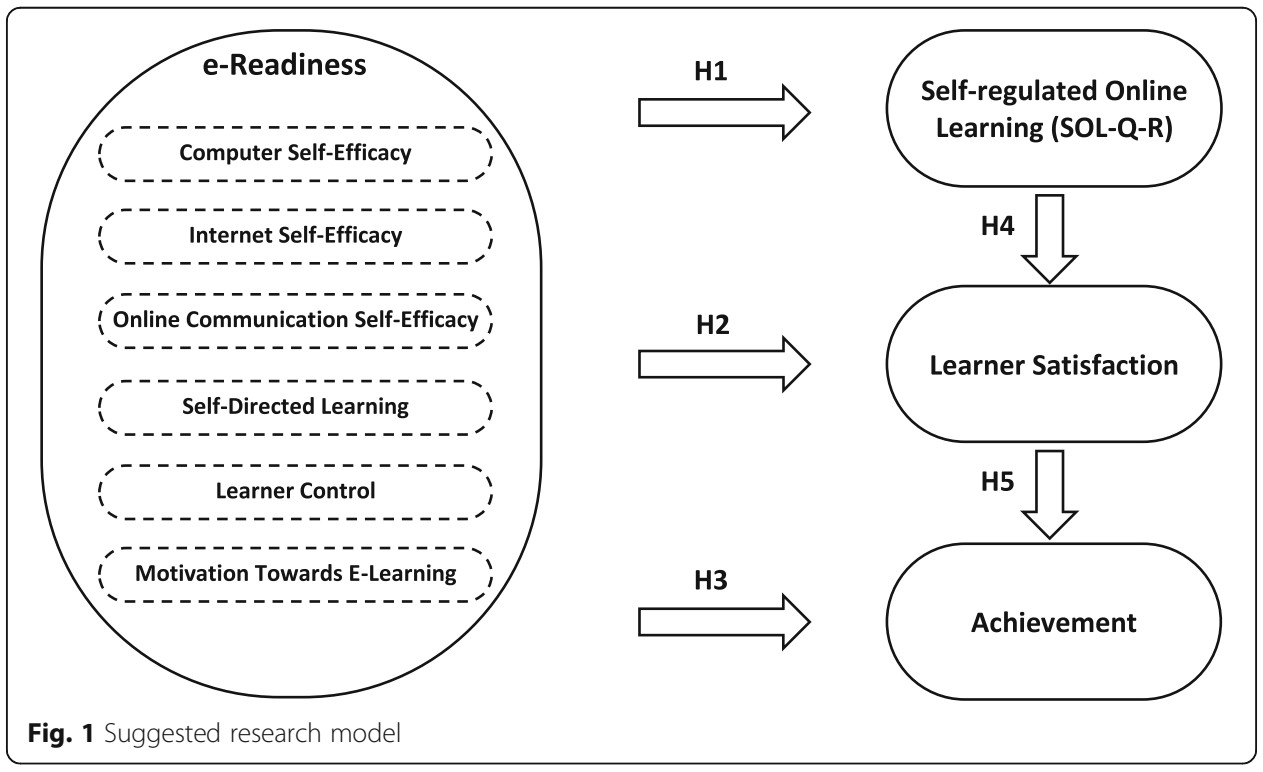


- H2: University students' readiness for e-learning (so their computer self-efficacy, internet self-efficacy, online communication self-efficacy, self-directed learning, learner control, and motivation toward e-learning) positively predicts their satisfaction with online environments.

- H3: University students' readiness for e-learning (so their computer self-efficacy, internet self-efficacy, online communication self-efficacy, self-directed learning, learner control, and motivation toward e-learning) positively predicts their academic achievement in the online courses that they take.

- H4: University students' self-regulation skills for online environments positively predict their satisfaction with online environments.

- H5: University students' satisfaction with online environments positively predicts their academic achievement in the online courses that they take.

\section{The problem statement}

The aim of this study is to reveal the relationship of readiness for e-learning in students taking campus-based courses via distance learning with their levels of online selfregulation skills, satisfaction, and academic achievement. With this aim, an attempt is made to find an answer to the following research problem:

- What are the relationships among university students' readiness for e-learning, their online self-regulation skills, satisfaction, and academic achievement?

\section{Method}

Considering the research problem stated above, a cross-sectional survey design was implemented in the study. Survey studies made in a universe consisting of many elements, in which the whole of the universe or a certain sample taken from it is used to make a general judgment about the universe. Studies that use a cross-sectional approach are those in which development is observed in separate groups considered to represent the various stages of development, and in one go at one point in time (Fraenkel, Wallen, \& Hyun, 2012).

\section{Participants}

In this study, data were gathered from students registered on common compulsory campus-based courses in order to collect data from students registered on different degree programs. In the autumn term of the 2018-2019 academic year at a state university in Turkey, there were 9816 students taking at least one of the campus-based common compulsory courses (Atatürk's Principles and Revolutionary History, Foreign Language, and Turkish Language) via distance learning. The Scale of University Students' Readiness for e-Learning, which was prepared as an online survey, the Revised Self-Regulated Online Learning Questionnaire, and the Satisfaction Levels Survey were completed voluntarily by 749 students. Then, 276 of the students who made up the study group were male, and 473 were female. Moreover, 478 of the students were studying in faculties, 92 in colleges, and 179 in vocational schools. The mean of participants' age is 20.40 . 


\section{Data collection tools}

Two scales and one survey were used as data collection tools in the study. These scales were the Scale of University Students' Readiness for e-Learning, and the Revised SelfRegulated Online Learning Questionnaire (SOL-Q-R). In addition, a survey was used in the study for determining students' levels of satisfaction with distance learning services.

\section{Scale of readiness for e-learning}

This scale was developed by Yurdugül and Demir (2017). The scale, which is of the 5point Likert type and was developed to determine students' levels of readiness for elearning, consists of 33 items and 6 subdimensions (computer self-efficacy, internet selfefficacy, online communication self-efficacy, self-directed learning, learner control, and motivation toward e-learning). To determine the reliability of the scale, the Cronbach's alpha internal consistency coefficients were calculated; these were found to be .84 for computer self-efficacy, .85 for internet self-efficacy, .84 for online communication selfefficacy, .88 for self-directed learning, .91 for learner control, and .95 for motivation toward e-learning. Overall Cronbach Alpha reliability coefficient of the scale was calculated as 0.93 (Yurdugül \& Demir, 2017).

Within the scope of this study, confirmatory factor analysis $(n=749)$ was performed to ensure the structural validity of the Scale of Readiness for e-Learning. According to the results of the confirmatory factor analysis, the scale had acceptable fit index values $\left(\mathrm{X}^{2} / \mathrm{df}=11.92, \mathrm{CFI}=.96\right.$, and RMSEA $\left.=.06\right)$. The factor loadings of the scale were seen to range between .76 and .93 . As a result of the reliability analysis that was made, the Cronbach's alpha internal consistency coefficients were calculated as .95 for the computer self-efficacy subdimension of the scale of readiness for e-learning, .95 for the internet self-efficacy subdimension, .93 for online communication self-efficacy, .96 for self-directed learning, .94 for learner control, and .96 for motivation toward e-learning.

\section{Revised Self-Regulated Online Learning Questionnaire}

In this study, the Revised Version of the Self-Regulated Online Learning Questionnaire (SOL-Q-R), developed by Jansen, Leeuwen, Janssen, and Kester (2018), was used. This revised version of the scale consists of 42 items of the 7-point Likert type and 7 subdimensions (metacognition before an activity, metacognition during an activity, metacognition after an activity, time management, environmental structuring, persistence, and help-seeking). The Turkish adaptation of the scale was made by the researchers in another study (Yavuzalp \& Bahcivan, 2020). For the structural validity of the scale, exploratory factor analysis was carried out by the researchers. As a result of the factor analysis, a one-dimensional structure emerged for the scale. According to the results of the analysis of the single-factor structure, it was reported that the factor loading distribution of the 42 items that emerged for the SOL-Q-R scale ranged between .81 and .92 , and that the mean factor loading value was .89 . Moreover, it was stated that the total eigenvalue of the scale was 33.55 and that this accounted for $79.39 \%$ of the total variance. The Cronbach's alpha internal consistency coefficient of .99 for the scale indicates a high level of reliability ( Yavuzalp \& Bahcivan, 2020).

Within the scope of this study, confirmatory factor analysis $(n=749)$ was performed to ensure the structural validity of the Revised Version of the Self-Regulated Online 
Learning Questionnaire. According to the results of the confirmatory factor analysis that was performed, it was calculated that the scale had acceptable fit index values $\left(x^{2} /\right.$ $\mathrm{df}=15.47, \mathrm{CFI}=.95$, and RMSEA $=.06)$ and that the factor loadings of the scale ranged from .81 to .92 . According to the results of the analysis that was made, the Cronbach's alpha internal consistency coefficient was calculated as .99 .

\section{Satisfaction with distance learning services}

Within the scope of the study, a satisfaction survey consisting of 7 questions was used to determine students' satisfaction with the services provided by the distance learning center and with the communication channels. While determining the questionnaire items, scale items were prepared by evaluating similar studies in the literature (Ilgaz \& Gülbahar, 2015; Kirmizi, 2015; Wang, Wang, \& Shee, 2007; R. Watkins et al., 2004). Students were asked to give a score ranging from 1 to 10 for each of the services specified in the survey questions.

While performing exploratory factor analysis for this scale, the maximum likelihood analysis method was used. As a result of the factor analysis that was made, a single dimension emerged for the scale. It was seen that the factor loadings of the scale items ranged from .90 to .96 , while the mean factor loading value was .93. Moreover, a Cronbach's alpha internal consistency coefficient of .98 was calculated for the scale.

\section{Academic achievement}

The average final grades obtained by the students from the campus-based courses that they took via distance learning (Atatürk's Principles and Revolutionary History, Foreign Language, and Turkish Language) were accepted as measures of their academic achievement. For calculating the average final grades, the grade of a student registered on one course was taken directly, while average final grades of students registered on more than one course were used by taking their arithmetic means.

\section{Data collection process}

With the aim of speeding up the data collection process, reaching a greater number of participants, and reducing the number of items that students had to reply to in one go, the scales were implemented at different times. In this context, the scale of readiness for e-learning was applied at the beginning of the academic year, the SOL-Q-R was applied at the end of the autumn semester, and the satisfaction survey was implemented at the end of the spring semester. For obtaining data for academic achievement, the average final grades obtained by the students in the courses they were registered on for the autumn term, when they responded to the survey, were used. The data set of the study encompasses the responses of students responding to all the scales. The scales and satisfaction survey were implemented as online surveys via the distance learning management system (LMS) of the university where the study was carried out. Each scale was published on the LMS for a period of 3 weeks and all students accessing the system were given the opportunity to respond. Since the scales, which were completed voluntarily by students taking campus-based common compulsory courses via distance learning, were each kept open on the LMS for 3 weeks, the data collection process lasted for a total of 9 weeks. During this period, 1767 different students responded 
voluntarily to the scales. However, the number of participants who replied to all the scales and to the survey was 749 .

\section{Data analysis}

Within the scope of the study, the data of students who responded to all 3 different scales for which data were collected were included in the analysis. In this context, the study results revealed that the data of 918 students made up the intersection set. Firstly, the normality distribution, linearity analysis, removal of outliers, and determination of the blank data of the research data were aimed for. With this aim, scales in which more than one item in the scale items had been left blank were removed from the research data. For those without missing or faulty data, outlier and normality analyses were made. After all analyses had been made and missing/faulty data (169) had been removed, the responses of 749 students made up the research data. Moreover, linearity analysis showed that all the continuous variables of the research presented significant correlations among themselves.

Within the scope of the study, it was aimed to reveal the structural relationships among the study variables regarding the problem statement. With this aim, the basic analysis method for the study was specified as structural equation modeling. This analysis was carried out with the AMOS software package.

\section{Results}

The relationships between readiness for e-learning, online self-regulation skills, satisfaction, and academic achievement in university students taking campus-based courses via distance learning were examined with structural equation modeling analysis. The structural model which shows the significant relationships that appeared is presented in Fig. 2. As a result of the analysis, it was seen that the model had acceptable fit values $\left(x^{2} / \mathrm{df}=\right.$ 4.11 , CFI $=.90$, and RMSEA $=.06$ ).

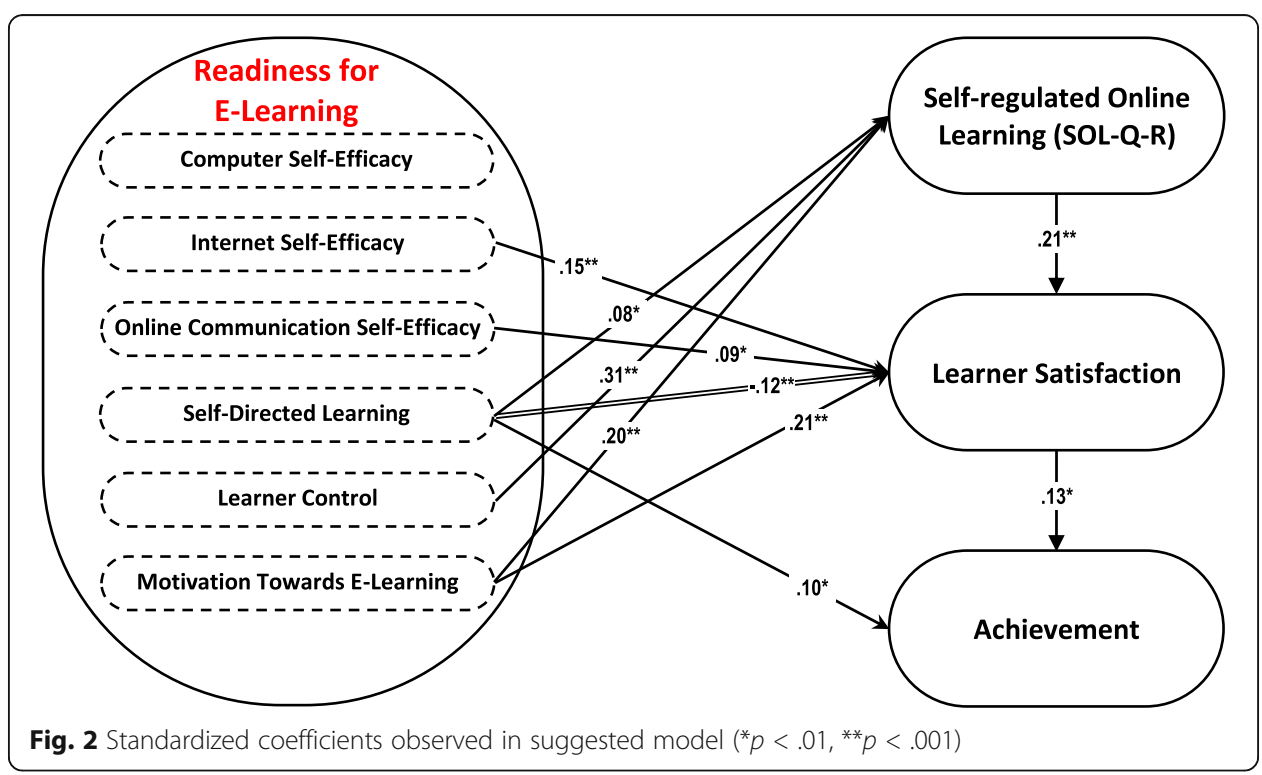


It can be seen that readiness for e-learning in university students taking campusbased courses via distance learning was a significant predictor of their self-regulated learning skills (H1). In other words, in terms of readiness for e-learning, an increase in their self-directed learning, learner control, and motivation toward e-learning positively predicted their self-regulated learning skills. Furthermore, in terms of regression weights, it can be said that the effect of the subdimensions of learner control and motivation toward e-learning on self-regulated learning skills was greater.

Moreover, it can be seen that the university students' readiness for e-learning was a significant predictor of their satisfaction with the distance learning centre (H2). When this observation is examined from between the students' readiness for e-learning and their self-regulated learning skills, while a positive effect is indicated in terms of internet self-efficacy, online communication self-efficacy and motivation toward e-learning, a negative effect is indicated in terms of self-directed learning. In this case, it is considered that while students' internet self-efficacy, online communication self-efficacy, and motivation toward e-learning increase, their self-regulated learning skills may also increase.

It is seen that the university students' readiness for e-learning was a partial predictor of their academic achievement (H3). However, it was observed that only the selfdirected learning dimension of the students' readiness for e-learning had a positive effect on their academic achievement, while the other dimensions did not have a significant effect.

On the other hand, the university students' self-regulated learning skills had a positive effect on their satisfaction with the distance learning centre (H4). In other words, an increase in students' self-regulated learning skills will have a positive effect on their satisfaction. Moreover, it is seen that the university students' satisfaction was a significant predictor of their academic achievement (H5). Based on this observation, it can be considered that students' satisfaction will have a positive effect on their academic achievement.

\section{Discussion and conclusion}

Considering the findings related to the structural model in which the hypotheses suggested in line with the aim of the research were tested, it was seen that hypotheses H1, $\mathrm{H} 2, \mathrm{H} 3, \mathrm{H} 4$, and $\mathrm{H} 5$ were partially confirmed.

It was observed that computer self-efficacy, which is one of the subdimensions of the readiness for e-learning scale, was not correlated with any of the other variables (selfregulation, satisfaction, and academic achievement) included in this research. This situation can be explained by the fact that all of the tools used by the students taking courses via distance learning at the university where the research was conducted are internet-based, and that the students can use the LMS with very basic computer usage skills. Moreover, it is known that in distance education courses, the instructors are more active than the students, and that since the lessons can be watched again, students generally prefer to watch archive recordings. However, M.H. Cho and Shen (2013) argued that in a nonsynchronous online learning environment, metacognitive self-regulation was not only correlated with students' learning and academic performance but was also positively related to their self-efficacy. 
When these situations are considered, in terms of students' self-efficacy in the subject of readiness for e-learning, mainly their internet and online communication selfefficacies may have come to the fore. In support of this view, Demir Kaymak and Horzum (2013) also stated that online communication self-efficacy had a significant positive relationship with readiness for e-learning and interaction (instructor-learner, learner-learner, learner-content). M.H. Cho and Kim (2013) revealed that students' mastery goal orientations and their interaction in online learning environments were positively correlated with their self-regulation.

Considering the findings of this study, computer self-efficacy was found not to be related to any of the other variables. In contrast with this finding, C.K. Lim (2001) stated that students' computer self-efficacy, which is one of the subdimensions of readiness for e-learning in online learning environments, was a predictor of their satisfaction. Similarly, Wu et al. (2010) reported that computer self-efficacy had a positive effect on students' satisfaction. Moreover, Eastin and LaRose (2000) stressed that computer and internet self-efficacy resulted in both improved performance in technical subjects such as downloading documents or online system management, and better performance in solving problems in online learning. However, in parallel with the research findings, Sun and Rueda (2012) stated that computer self-efficacy was not correlated with selfregulated learning skills. Moreover, Kirmizi (2015) stated in his study that although there was a positive correlation between computer/internet self-efficacy and satisfaction, these variables were not among the predictors of satisfaction.

Studies show that self-regulation is critical for determining students' successful learning experiences in online learning environments (M.H. Cho \& Kim, 2013). Yakin and Tinmaz (2013) state that readiness for e-learning has a significant effect on users' adoption of technological innovations. In this context, there are studies which state that readiness for e-learning is effective on students' achievement and satisfaction (A.R. Artino, 2009; S.B. Eom, 2014; Galy et al., 2011; Kruger-Ross \& Waters, 2013; S.S. Liaw \& Huang, 2013; Tsai \& Tsai, 2003; Yilmaz, 2017).

In their study in which they examined the factors affecting student satisfaction in the context of web-based distance learning systems, Shee and Wang (2008) revealed that the user-friendliness and stable operation of the interface used by learners was more effective than communication in the learning community. In other conducted studies, however, it is stated that levels of readiness for the internet and technology were among the most important factors determining e-learners' satisfaction with the LMS (Parnell \& Carraher, 2003; R. Watkins et al., 2004). In their online learning study, Kuo et al. (2014) found that students' internet self-efficacy, self-regulated learning, learner-learner interaction, learner-instructor interaction, and learner-content interaction were correlated with their satisfaction. A.R. Artino (2009) reported that motivation variables such as self-efficacy and task value were positive predictors of students' course satisfaction. When the findings of this study are taken into consideration, it is seen that internet self-efficacy, online communication self-efficacy and motivation, which are subdimensions of readiness for e-learning, are positive predictors of satisfaction, whereas selfdirected learning is a negative predictor. In support of the findings obtained, in the study made by Yilmaz (2017), it is stated that online communication self-efficacy has a positive effect on satisfaction. S.S. Liaw and Huang (2013) found that satisfaction was related to self-efficacy, anxiety, and interactive learning environments. Moreover, A.R. 
Artino (2009) revealed that motivation variables including self-efficacy and task value were predictors of satisfaction. Moreover, there are other studies which state that motivation has a positive effect on satisfaction (M.H. Cho \& Heron, 2015; Kirmizi, 2015; E. Yukselturk, 2009). On the other hand, with a different view, there are also studies stating that internet self-efficacy, which is one of the subdimensions of readiness for elearning, is not related to or is not a predictor of student satisfaction (Kuo et al., 2014).

One of the findings of this study was that self-directed learning had a significant negative relationship with satisfaction. It is reported in the literature that together with learner control, self-directed learning is one of the important predictors of satisfaction (Hao, 2016; Yilmaz, 2017). Kirmizi (2015) stated that students who possess self-directed learning skills will be able to conduct their own work plans and that they have high expectations from their learning. In this context, it can be considered that the expectations of the students participating in this study were not adequately met. This situation needs to be analyzed in depth by means of qualitative studies.

Furthermore, learners' levels of online readiness are a directly effective structure for their success (A.R. Artino, 2009; Dikbas Torun, 2020; Galy et al., 2011; Kruger-Ross \& Waters, 2013). Studies reveal that the internet self-efficacy subdimension of readiness for e-learning has a positive effect on students' achievement in web-based learning environments (Tsai \& Tsai, 2003). Another study reveals that there is a strong correlation between students' e-learning readiness and academic achievement (Dikbas Torun, 2020). On the other hand, Clark (1983) claims that in the process of providing education, technology is only a tool and does not have an effect on student success. Considering the findings of this study, in support of Clark's (1983) ideas, it was revealed that readiness for e-learning was directly related to technology and that none of the computer, internet, or online communication self-efficacy subdimensions was related to achievement. In contrast with the findings obtained, there are studies which report that the computer, internet, and online communication self-efficacy (A.R. Artino, 2009; Kruger-Ross \& Waters, 2013; Tsai \& Tsai, 2003; Yakin \& Tinmaz, 2013), and learner control and motivation (M.H. Cho \& Heron, 2015; M.H. Cho \& Kim, 2013; Hao, 2016; E. Yukselturk, 2009) subdimensions are correlated with achievement.

However, in the findings of this study, only the self-directed learning dimension of readiness for e-learning had a positive relationship with achievement. Similar to the revealed findings, in the study made by Kirmizi (2015), it was stated that self-directed learning was one of the most important predictors of achievement in distance learning programs.

Song et al. (2004) state that for online learners, course design and time management are important components of successful online learning, while lack of communication and technical problems are complicating factors for students. S.K. Parahoo et al. (2016) revealed that learner-learner interaction has an important effect on satisfaction. Similar findings have also been revealed by other researchers (Einarson \& Matier, 2005; Hollenbeck et al., 2011; Ivankova \& Stick, 2007). M.H. Cho and Heron (2015) revealed that motivation, which is one of the components of self-regulation, and emotion, have a significant effect on students' learning experiences such as achievement, satisfaction, and passing or failing the course.

When the findings of this study are considered, it is seen that many of the aforementioned studies are such as to support the findings of the research. However, contrary to 
the findings of the study, S.B. Eom (2014) stated that students' self-regulated learning skills are not related to satisfaction. Although the studies in the literature state the variables that reveal student satisfaction, there are also studies which state that cultural differences can have an effect on student satisfaction (Smith, Coldwell, Smith, \& Murphy, 2005; Zhu, 2012). Therefore, this factor should not be ignored in studies conducted on student satisfaction.

Considering the relationships between students' satisfaction and academic achievement, it is expected that these two variables will be highly correlated with each other. There are studies which report high rates of correlation between student satisfaction and academic achievement in online learning environments (Ali \& Ahmad, 2011; DeBourgh, 1999; E. Yukselturk \& Yildirim, 2008). Naturally, it is expected that students who are highly motivated for e-learning will also have high levels of satisfaction and achievement (E. Yukselturk, 2009).

Considering the findings and arguments stated above, it can be said that this study has five different conclusions:

1. University students' self-directed learning, learner control, and motivation toward e-learning dimensions of readiness for e-learning significantly predict their selfregulation skills.

2. University students' internet self-efficacy, online communication self-efficacy, selfdirected learning, and motivation toward e-learning dimensions of readiness for elearning significantly predict their satisfaction.

3. University students' self-directed learning significantly predicts their academic achievement.

4. University students' self-regulation skills significantly predict their satisfaction.

5. University students' satisfaction significantly predicts their academic achievement.

\section{Implications}

Considering that the university students' readiness for e-learning significantly predicted all the other variables, it is recommended that integration of various practices should be attempted in order to increase levels of readiness for e-learning environments. In this context, it can be suggested that distance learning courses can be taken not from the first grade onwards, but at higher class levels. E. Yukselturk (2009) states that academic maturity can have a positive effect on students' satisfaction and achievement. Moreover, offering the information and communication technology course in the first grade in all departments can have a positive effect in terms of increasing students' readiness in this subject.

A significant positive effect of self-regulation skills on student satisfaction, and of satisfaction on academic achievement were observed. In this context, it is suggested that studies be made aimed at increasing university students' self-regulation skills for elearning environments and satisfaction. Especially, related to the satisfaction quantitative and/or qualitative assessment tools can be used to determine how we can increase students' satisfaction with online learning environments. In this regard, a bottom-up strategy can apply to determine contents of distance education courses. Bottom-up designed contents may contribute positively to their self-regulation skills and satisfaction. 
It was observed that the effect of readiness for e-learning on academic achievement was realized only via the self-directed learning dimension, but that the other four dimensions did not have any effect. This situation does not correspond to the expectations of the researchers who conducted this research. It can be recommended that future researchers investigate the reasons for this situation with qualitative studies.

\section{Code availability}

Not applicable.

\section{Authors' contributions}

All the steps of the research were conducted by the authors with equal access. Determining the research questions, preparing the instrument, collecting and analyzing the data, and constructing the manuscript were achieved together.

\section{Funding}

Not applicable.

\section{Availability of data and materials}

The data of this study is available from the corresponding author on reasonable request.

\section{Declarations}

\section{Competing interests}

The authors declare that they have no competing interests.

\section{Author details}

${ }^{1}$ Faculty of Education, Department of Computer Education \& Instructional Technologies, Bolu Abant Izzet Baysal University, Bolu, Turkey. 'Faculty of Education, Department of Science Education, Bolu Abant Izzet Baysal University, Bolu, Turkey.

Received: 14 September 2020 Accepted: 27 April 2021

Published online: 24 May 2021

\section{References}

Abar, B., \& Loken, E. (2010). Self-regulated learning and self-directed study in a pre-college sample. Learning and Individual Differences, 20(1), 25-29. https://doi.org/10.1016/j.lindif.2009.09.002.

Alem, F., Plaisent, M., Zuccaro, C., \& Bernard, P. (2016). Measuring e-Learning readiness concept: Scale development and validation using structural equation modeling. International Journal of e-Education, e-Business, e-Management and eLearning, 6(4), 193.

Ali, A., \& Ahmad, I. (2011). Key factors for determining student satisfaction in distance learning courses: A study of Allama labal Open University. Contemporary Educational Technology, 2(2), 118-134.

Artino, A. R. (2009). Online learning: Are subjective perceptions of instructional context related to academic success? Internet and Higher Education, 12(3-4), 117-125. https://doi.org/10.1016/j.iheduc.2009.07.003.

Artino, A. R. (2010). Online or face-to-face learning? Exploring the personal factors that predict students' choice of instructional format. Internet and Higher Education, 13(4), 272-276. https://doi.org/10.1016/j.iheduc.2010.07.005.

Yavuzalp, N., \& Bahcivan, E. (2020). The online learning self-efficacy scale: its adaptation into Turkish and interpretation according to various variables. Turkish Online Journal of Distance Education, 21(1), 31-44. https://doi.org/10.17718/tojde. 674388.

Cho, M. H., \& Heron, M. L. (2015). Self-regulated learning: The role of motivation, emotion, and use of learning strategies in students' learning experiences in a self-paced online mathematics course. Distance Education, 36(1), 80-99. https://doi. org/10.1080/01587919.2015.1019963.

Cho, M. H., \& Kim, B. J. (2013). Students' self-regulation for interaction with others in online learning environments. The Internet and Higher Education, 17, 69-75. https://doi.org/10.1016/j.iheduc.2012.11.001.

Cho, M. H., \& Shen, D. (2013). Self-regulation in online learning. Distance Education, 34(3), 290-301. https://doi.org/10.1080/01 587919.2013 .835770

Clark, R. E. (1983). Reconsidering research on learning from media. Review of Educational Research, 53(4), 445-459. https://doi. org/10.3102/00346543053004445.

Croxton, R. A. (2014). The role of interactivity in student satisfaction and persistence in online learning. MERLOT Journal of Online Learning and Teaching, 10(2), 314-325.

Debourgh, G. A. (1999). Technology is the tool, teaching is the task: Student satisfaction in distance learning. In Society for Information Technology \& Teacher Education International Conference (pp. 131-137). Association for the Advancement of Computing in Education (AACE).

Demir Kaymak, Z., \& Horzum, M. B. (2013). Relationship between online learning readiness and structure and interaction of online learning students. Educational Sciences: Theory \& Practice, 13(3), 1792-1797.

Demirtas, Z. (2010). The relationship between school culture and student achievement. Education and Science, 35(158), 3-13.

Dikbas Torun, E. (2020). Online distance learning in higher education: E-learning readiness as a predictor of academic achievement. Open Praxis, 12(2), 191-208. https://doi.org/10.5944/openpraxis.12.2.1092.

Eastin, M. S., \& LaRose, R. (2000). Internet self-efficacy and the psychology of the digital divide. Journal of Computer-Mediated Communication, 6(1). https://doi.org/10.1111/j.1083-6101.2000.tb00110.x. 
Einarson, M. K., \& Matier, M. W. (2005). Exploring race differences in correlates of seniors' satisfaction with undergraduate education. Research in Higher Education, 46(6), 641-676. https://doi.org/10.1007/s11162-004-4138-0.

Eom, S. B. (2014). Understanding e-learners' satisfaction with learning management systems. Bulletin of the IEEE Technical Committee on Learning Technology, 16(2), 3.

Fraenkel, J. R., Wallen, N. E. \& Hyun, H. H. (2012). How to design and evaluate research in education (8th ed.). New York, NY: McGraw-Hill.

Galy, E., Downey, C., \& Johnson, J. (2011). The effect of using E-learning tools in online and campus-based classrooms on student performance. Journal of Information Technology Education, 10, 209-230. https://doi.org/10.28945/1503.

Gülbahar, Y. (2012). E-Öğrenme. Ankara: Pegem Akademi.

Hao, Y. (2016). Middle school students' flipped learning readiness in foreign language classrooms: Exploring its relationship with personal characteristics and individual circumstances. Computers in Human Behavior, 59, 295-303. https://doi.org/1 0.1016/j.chb.2016.01.031.

Hollenbeck, C. R., Mason, C. H., \& Song, J. H. (2011). Enhancing student learning in marketing courses: an exploration of fundamental principles for website platforms. Journal of Marketing Education, 33(2), 171-182. https://doi.org/10.1177/02 73475311410850 .

Holmes, B., \& Gardner, J. (2006). E-learning: concepts and practice. London: SAGE Publications.

Hong, K. S. (2002). Relationships between students' and instructional variables with satisfaction and learning from a Webbased course. Internet and Higher Education, 5(3), 267-281. https://doi.org/10.1016/S1096-7516(02)00105-7.

Hong, K. S., Lai, K. W., \& Holton, D. (2003). Students' satisfaction and perceived learning with a web-based course. Educational Technology \& Society, 6(1), 116-124.

Hukle, D. R. L. (2009). An evaluation of readiness factors for online education (Unpublished doctoral dissertation). Mississippi: Mississippi State University.

Hung, M., Chou, C., Chen, C., \& Own, Z. (2010). Learner readiness for online learning: Scale development and student perceptions. Computers \& Education, 55(3):1080-1090. https://doi.org/10.1016/j.compedu.2010.05.004.

Ilgaz, H., \& Gülbahar, Y. (2015). A snapshot of online learners: e-readiness, e-satisfaction and expectations. The International Review of Research in Open and Distributed Learning, 16(2). doi: https://doi.org/10.19173/irrodl.v16i2.2117, 16, 2

Ivankova, N. V., \& Stick, S. L. (2007). Students' persistence in a distributed doctoral program in educational leadership in higher education: A mixed methods study. Research in Higher Education, 48(1), 93-135. https://doi.org/10.1007/s11162006-9025-4

Jansen, R. S., Van Leeuwen, A., Janssen, J., \& Kester, L. (2018). Validation of the revised self-regulated onilne learning questionnaire. Lifelong Technology-Enhanced Learning, 11082, 116-121. https://doi.org/10.1007/978-3-319-98572-5_9.

Johnson, R. D., Hornik, S., \& Salas, E. (2008). An empirical examination of factors contributing to the creation of successful elearning environments. International Journal of Human-Computer Studies, 66(5), 356-369. https://doi.org/10.1016/j.ijhcs.2 007.11.003.

Kaur, K., \& Abas, Z. W. (2004). An assessment of e-learning readiness at the Open University Malaysia. Paper presented at the international conference on computers in education (ICCE2004), Melbourne, Australia, 1017-1022.

Keramati, A., Afshari-Mofrad, M., \& Kamrani, A. (2011). The role of readiness factors in e-learning outcomes: an empirical study. Computers \& Education, 57(3), 1919-1929. https://doi.org/10.1016/j.compedu.2011.04.005.

Kirmizi, Ö. (2015). The influence of learner readiness on student satisfaction and academic achievement in an online program at higher education. Turkish Online Journal of Educational Technology-TOJET, 14(1), 133-142.

Klein, H. J., Noe, R. A., \& Wang, C. (2006). Motivation to learn and course outcomes: The impact of delivery mode, learning goal orientation, and perceived barriers and enablers. Personnel Psychology, 59(3), 665-703. https://doi.org/10.1111/j.17446570.2006.00050.x.

Kruger-Ross, M., \& Waters, R. D. (2013). Predicting online learning success: Applying the situational theory of publics to the virtual classroom. Computers \& Education, 61, 176-184. https://doi.org/10.1016/j.compedu.2012.09.015.

Kuo, Y. C., Walker, A. E., Schroder, K. E. E., \& Belland, B. R. (2014). Interaction, internet self-efficacy, and self-regulated learning as predictors of student satisfaction in online education courses. The Internet and Higher Education, 20, 35-50. https://doi. org/10.1016/j.iheduc.2013.10.001.

Liaw, S. S., \& Huang, H. M. (2013). Perceived satisfaction, perceived usefulness and interactive learning environments as predictors to self-regulation in e-learning environments. Computers \& Education, 60(1), 14-24. https://doi.org/10.1016/j. compedu.2012.07.015.

Liaw, S. S., Huang, H. M., \& Chen, G. D. (2007). An activity-theoretical approach to investigate learners' factors toward elearning systems. Computers in Human Behavior, 23(4), 1906-1920. https://doi.org/10.1016/j.chb.2006.02.002.

Lim, C. K. (2001). Computer self-efficacy, academic self-concept, and other predictors of satisfaction and future participation of adult distance learners. American Journal of Distance Education, 15(2), 41-51. https://doi.org/10.1080/08923640109527083.

Lin, J. S. C., \& Hsieh, P. L. (2007). The influence of technology readiness on satisfaction and behavioral intentions toward selfservice technologies. Computers in Human Behavior, 23(3), 1597-1615. https://doi.org/10.1016/j.chb.2005.07.006.

Lin, K. M. (2011). e-Learning continuance intention: Moderating effects of user e-learning experience. Computers \& Education, 56(2), 515-526. https://doi.org/10.1016/..compedu.2010.09.017.

Lopes, C. T. (2007). Evaluating e-learning readiness in a health sciences higher education institution. In IADIS International Conference Elearning.

Machado, C. (2007). Developing an e-readiness model for higher education institutions: Results of a focus group study. British Journal of Educational Technology, 38(1), 72-82. https://doi.org/10.1111/j.1467-8535.2006.00595.x.

Moore, M. G. (2005). Blended learning. The American Journal of Distance Education, 19(3), 129-132. https://doi.org/10.1207/s1 5389286ajde1903_1.

Muilenburg, L. Y., \& Berge, Z. L. (2005). Student barriers to online learning: A factor analytic study. Distance Education, 26(1), 29-48. https://doi.org/10.1080/01587910500081269.

Nwagwu, W. E. (2020). E-learning readiness of universities in Nigeria-what are the opinions of the academic staff of Nigeria's premier university? Education and Information Technologies, 25(2), 1343-1370. https://doi.org/10.1007/s10639-019-10026-0. 
Ozturk, D. S., Ozturk, F., \& Ozen, R. (2018). The relationship between prospective teachers' readiness and satisfactions about web-based distance education. Turkish Online Journal of Distance Education, 19(1), 147-162. https://doi.org/10.17718/ tojde.382791.

Paechter, M., Maier, B., \& Macher, D. (2010). Students' expectations of, and experiences in e-learning: Their relation to learning achievements and course satisfaction. Computers \& Education, 54(1), 222-229. https:/doi.org/10.1016/j.compedu.2009.08.005.

Parahoo, S. K., Santally, M. I., Rajabalee, Y., \& Harvey, H. L. (2016). Designing a predictive model of student satisfaction in online learning. Journal of Marketing for Higher Education, 26(1), 1-19. https://doi.org/10.1080/08841241.2015.1083511.

Parnell, J. A., \& Carraher, S. (2003). The management education by internet readiness (MEBIR) scale: Developing a scale to assess personal readiness for Internet-mediated management education. Journal of Management Education, 27(4), 431446. https://doi.org/10.1177/1052562903252506.

Pillay, H., Irving, K., \& Tones, M. (2007). Validation of the diagnostic tool for assessing tertiary students' readiness for online learning. Higher Education Research \& Development, 26(2), 217-234. https://doi.org/10.1080/07294360701310821.

Pintrich, P. R. (2004). A conceptual framework for assessing motivation and self-regulated learning in college students. Educational Psychology Review, 16(4), 385-407. https://doi.org/10.1007/s10648-004-0006-X.

Shee, D. Y., \& Wang, Y. S. (2008). Multi-criteria evaluation of the web-based e-learning system: A methodology based on learner satisfaction and its applications. Computers \& Education, 50(3), 894-905. https:/doi.org/10.1016/j.compedu.2006.09.005.

Smith, P. J., Coldwell, J., Smith, S. N., \& Murphy, K. L. (2005). Learning through computer-mediated communication: a comparison of Australian and Chinese heritage students. Innovations in Education and Teaching International, 42(2), 123134. https://doi.org/10.1080/14703290500062441.

So, T., \& Swatman, P. M. (2006). e-Learning readiness of Hong Kong teachers. University of South Australia http://www.insyl. unisa.edu.au/publications/working-papers/2006-05.pdf.

Song, L., Singleton, E. S., Hill, J. R., \& Koh, M. H. (2004). Improving online learning: Student perceptions of useful and challenging characteristics. The Internet and Higher Education, 7(1), 59-70. https://doi.org/10.1016/j.iheduc.2003.11.003.

Stansfield, M., McLellan, E., \& Connolly, T. M. (2004). Enhancing student performance in online learning and traditional face-toface class delivery. Journal of Information Technology Education, 3, 173-188. https://doi.org/10.28945/296.

Sun, J. C. Y., \& Rueda, R. (2012). Situational interest, computer self-efficacy and self-regulation: Their impact on student engagement in distance education. British Journal of Educational Technology, 43(2), 191-204. https://doi.org/10.1111/j.14 67-8535.2010.01157.x.

Tsai, M. J., \& Tsai, C. C. (2003). Information searching strategies in web-based science learning: The role of internet selfefficacy. Innovations in education and Teaching International, 40(1), 43-50. https://doi.org/10.1080/1355800032000038822

Valtonen, T., Kukkonen, J., Dillon, P., \& Väisänen, P. (2009). Finnish high school students' readiness to adopt online learning: Questioning the assumptions. Computers \& Education, 53(3), 742-748. https://doi.org/10.1016/j.compedu.2009.04.014.

Walker, C. E., \& Kelly, E. (2007). Online instruction: Student satisfaction, kudos, and pet peeves. Quarterly Review of Distance Education, 8(4), 309-319.

Wang, Y. S., Wang, H. Y., \& Shee, D. Y. (2007). Measuring e-learning systems success in an organizational context: Scale development and validation. Computers in Human Behavior, 23(4), 1792-1808. https://doi.org/10.1016/j.chb.2005.10.006.

Warner, D., Christie, G., \& Choy, S. (1998). Readiness of VET clients for flexible delivery including on-line learning. Brisbane: Australian National Training Authority. http://hdl.voced.edu.au/10707/33256.

Watkins, R., \& Corry, M. (2005). E-Learning companion: a student's guide to online success. New York: Houghton Mifflin.

Watkins, R., Leigh, D., \& Triner, D. (2004). Assessing readiness for e-learning. Performance Improvement Quarterly, 17(4), 66-79.

Wu, J. H., Tennyson, R. D., \& Hsia, T. L. (2010). A study of student satisfaction in a blended e-learning system environment. Computers \& Education, 55(1), 155-164. https://doi.org/10.1016/j.compedu.2009.12.012.

Yakin, I. \& Tinmaz, H. (2013). An important dimension in distance education: E-readiness for preservice teachers. Proceeding of XV. Akademik Bilişim AB'13 (pp 953-958). Antalya, Turkey: Mediterranean University, Turkey.

Yilmaz, R. (2017). Exploring the role of e-learning readiness on student satisfaction and motivation in flipped classroom. Computers in Human Behavior, 70, 251-260. https://doi.org/10.1016/j.chb.2016.12.085.

Yukselturk, E. (2009). Do entry characteristics of online learners affect their satisfaction? International Journal on E-Learning, $8(2), 263-281$

Yukselturk, E., \& Bulut, S. (2007). Predictors for student success in an online course. Journal of Educational Technology \& Society, 10(2), 71-83.

Yukselturk, E.. \& Yildirim, Z. (2008). Investigation of interaction, online support, course structure and flexibility as the contributing factors to students' satisfaction in an online certificate program. Journal of Educational Technology \& Society, $11(4), 51-65$.

Yurdugül, H., \& Demir, Ö. (2017). An investigation of pre-service teachers' readiness for e-learning at undergraduate level teacher training programs: The case of Hacettepe University. Hacettepe University Journal of Education, 32(4), 896-915. https://doi.org/10.16986/HUJE.2016022763.

Zhu, C. (2012). Student satisfaction, performance, and knowledge construction in online collaborative learning. Journal of Educational Technology \& Society, 15(1), 127-136.

Zimmerman, B. J. (2011). Motivational sources and outcomes of self-regulated learning and performance: Graduate center of city university of new york. In B. J. Zimmerman, \& D. H. Schunk (Eds.), Handbook of self-regulation of learning and performance, (pp. 63-78). New York, NY: Routledge.

Zimmerman, B. J., \& Schunk, D. H. (2011). Self-regulated learning and performance: An introduction and an overview. In B. J. Zimmerman, \& D. H. Schunk (Eds.), Handbook of self-regulation of learning and performance, (pp. 1-12). New York, NY: Routledge.

\section{Publisher's Note}

Springer Nature remains neutral with regard to jurisdictional claims in published maps and institutional affiliations. 